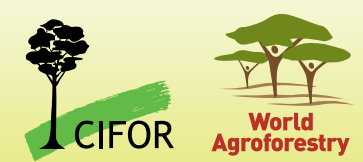

\title{
Tenure reform and perceived food security in Indonesia An exploratory study
}

\author{
Nining Liswanti, Deborah Kirby, Ade Tamara, Kartika Sari Juniwaty and Esther Mwangi
}

\section{Key messages}

- Land and forest tenure reform has been expanding globally, increasingly with the aim of improving the livelihoods and food security of indigenous people and local communities through securing forest access.

- In Indonesia, legal rights for local communities to access and manage state forests were partially recognised in 1999. Social forestry only started to advance in 2014, however, following the government's pledge to transfer the management of 12.7 million ha of forest to forest-dependent communities. Evaluating the impact of these forest tenure reforms on local communities' food security is critical to understanding the effectiveness of the reforms.

- CIFOR has developed a framework to assess the impact of forest tenure reform in Indonesia by comparing the perception of current levels of food security and the perception of changes in food security of communities living in areas that have undergone forest tenure reform with those living in non-reformed forest areas.

- Communities' perceptions of food security are influenced more by household characteristics and level of village development than by forest tenure reform status - the higher the village development, the greater the perception of food security. However, communities that have undergone forest tenure reform are more likely to perceive that their food security status has improved than those who have not.

- Communities in customary areas perceived higher food security, however those who had poor access to forests previously, such as those in reform areas, benefitted from forest access through reforms and thus perceived an improvement in food security conditions.

\section{Setting the scene: forest tenure reform and forest benefits}

Land and forest tenure reforms that increase forest area under the ownership or management of forest communities have become more widespread globally in the past decades. To date, 26 percent of forests and lands in Asia, Africa and Latin America have been allocated to local and indigenous communities, along with significant management rights and responsibilities (Rights and Resources Initiative 2020).

Among other things, many forest tenure reforms today aim to improve access to forests by indigenous people and local communities. If appropriate policies and innovative practices are promoted and well implemented, forest tenure reform increases communities' access to local food and non-food products and may contribute to improved livelihoods and food security. ${ }^{1}$ However, evaluations of forest tenure reform

Food security encompasses not only calorific intake but also 'secure access to the foods needed for a nutritionally balanced diet' (Sunderland 2011; Sunderland et al. 2013). indicate that the actual contribution of forest reform to the livelihoods of forest-dependent communities is below expectations (e.g. Larson et al. 2019).

The International Union of Forest Research Organizations (2015) highlights the relationship between access to forest/ tree-based systems and an increase in the consumption of fruits and vegetables. Many rural communities rely on forests for edible plants and wild meat, which support their food security and often contribute to household cash income as well as serving as a safety net during lean seasons and times of shock (Sunderland 2011; Sunderland et al. 2013). Losing access to these forest resources could negatively influence nutrition intake for forest-dependent communities and increase their vulnerability in times of stress (e.g. with compromised access to food markets or crop failure).

Given the particularly high levels of biodiversity found in Indonesian forests, they have high potential to provide a range of nutritious foods to communities who have access to them - Sukara (2014) found 51 edible fruits, 21 vegetables 
and 6 spices in the $300+$ plant species in Jambi Province, and Pawera et al. (2020) found 40 species of wild food plants in West Sumatra.

Forest tenure reform in Indonesia followed the enactment of law no. 41 in 1999, which provides partial rights for local communities to access and manage state forests through social forestry schemes. It was not until 2014, however, that social forestry started to advance following the commitment of the newly elected president to transfer the management of 12.7 million ha of forest to forestdependent communities.

Indonesia has five social forestry schemes: i) community forestry (Hutan Kemasyarakatan); ii) community plantation forestry (Hutan Tanaman Rakyat); iii) partnership forestry - between a company (state or private) and the local community; iv) customary forest (Hutan Adat); and v) village forestry (Hutan Desa). These schemes differ in function and requirements dependent on whether the forest is part of a production forest zone or protected forest zone. However, although differing in approach, all these schemes aim to improve communities' access to forest resources, including food.

While community forestry can be awarded to forest farmers in areas within a production forest zone (for timber extraction) or in protected forest zones (for non-timber forest products and environmental services), community plantation forestry can only be granted to community groups in production forest zones. Partnership forestry allows for collaboration between community groups and companies with timber concessions.

Customary forest is located within the territory of communities governed by customary laws, which can be fully managed by them. Formal recognition of customary forest use was made possible in Indonesia in 2013.

Knowledge of the relationship between forest tenure reform and food security is still limited in Indonesia. CIFOR has therefore developed a conceptual framework and undertaken analysis to assess the potential benefits of reforms for food security.

\section{Forest tenure and food security}

The relationship between land tenure and food security is complex (Holden and Ghebru 2016), and forest tenure reform may influence food security either directly, if the forest is a source of nutritious food (Ickowitz 2016), or indirectly through increased income from the sale of forest products, such as coffee, (Siscawati et al. 2017) or nontangible forest benefits, such as ecotourism.
With the objective of understanding the direct effect of forest tenure reform on food security, i.e. increased access to food, in Indonesia, CIFOR engaged in an analysis of the perception of level and change of household food security of forestdependent communities who have experienced forest tenure reform with those who have not.

Figure 1 shows a plausible direct pathway of the relationship between forest tenure reform on food security to be tested. Communities are placed under one of two conditions: i) forest tenure reforms are in place that have benefited the local community in terms of improved forest access and improved forest condition, or ii) no forest tenure reforms are in place.

Forest condition in areas with reform tend to improved following reform, with reduced access of outside interests and increased local community investment, with support of a variety of actors, resulting in improved food security. In areas with no forest tenure change, forest access is expected to have remained unchanged, although the forest condition may have deteriorated due to illegal 'open access' activity. We therefore expected there to be no change in food security in the local community over time.

In addition to forest tenure reform, other development programs can be implemented in the communities, which could affect development status of the community and may have influence on food security, e.g. building of infrastructure to increase access to markets (Ickowitz et al. 2016). Hence, to account for differences in community development, the Village Development Index, ${ }^{2}$ comprising five indices (basic services, infrastructure, accessibility/transportation, public service and government administration), ${ }^{3}$ was incorporated into the analysis.

Three research sites comprising 16 villages under three different forms of forest tenure were selected across Indonesia: in Maluku, West Kalimantan and Lampung provinces (Figure 2 and Table 1). These sites encompassed i) six villages in three districts in Lampung Province with reform through three different social forestry schemes (partnership forestry, community forestry and community plantation forestry), which have been in place since 1991, 2000 and 2010, respectively; ii) four villages in West Kalimantan Province that, at the time of the study, had undergone reform

2 Source: Badan Perencanaan Pembangunan Nasional dan Badan Pusat Statistik 2015. Indeks Pembangunan Desa 2014. Tantangan Pemenuhan Standar Pelayanan Minimum Desa. Jakarta.

3 The Village Development Index (VDI) describes the availability and accessibility of services to rural communities and is used by local government to monitor and prioritize village development. Covering 74,000 villages, the VDI places all villages into three categories: independent, developing and disadvantaged. Nationally, the majority of villages are categorized as developing and only $4 \%$ are categorized as independent. 


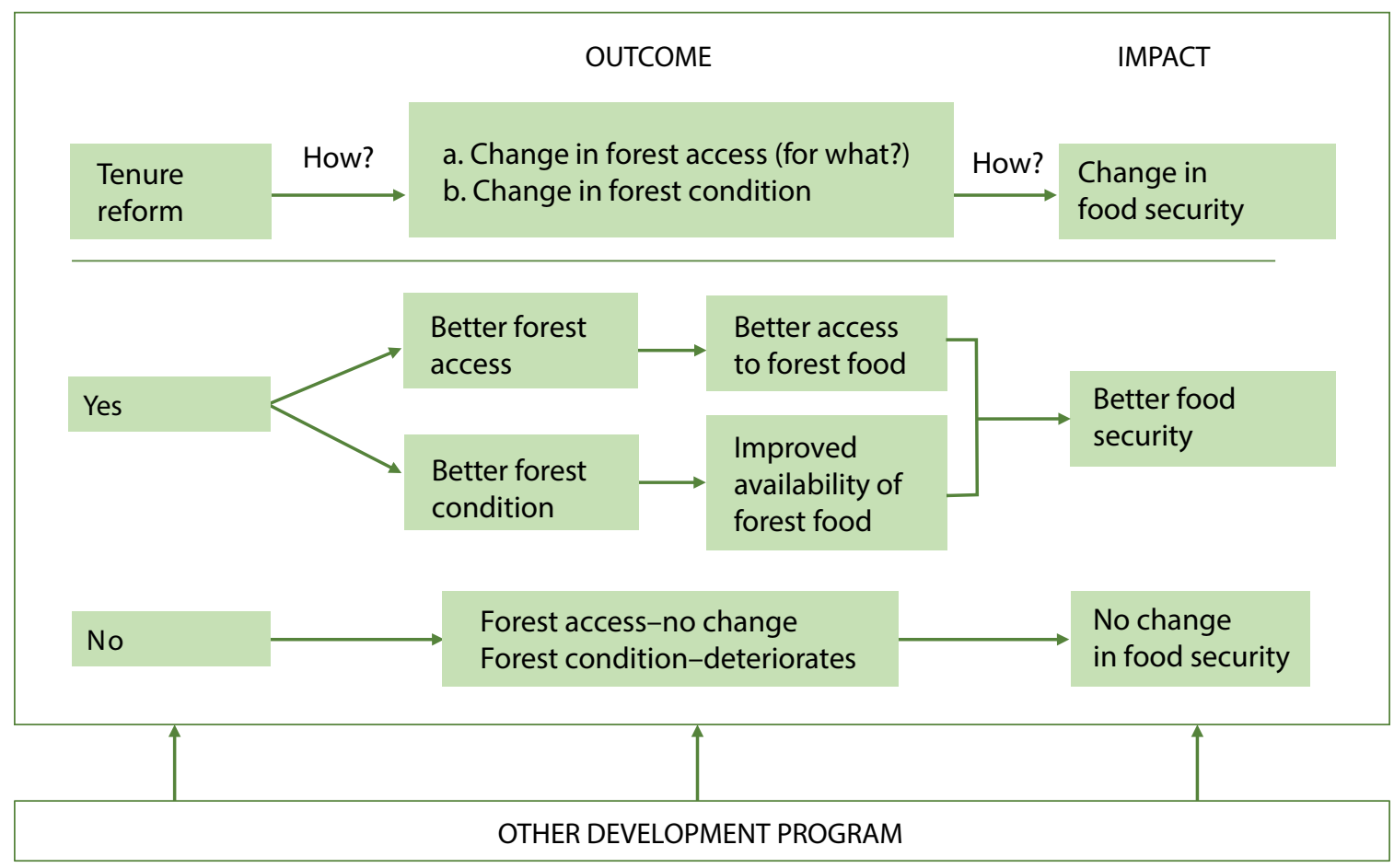

Figure 1. Conceptual framework of forest reform implementation in three provinces

Table 1. Details of research sites

\begin{tabular}{lll}
\hline Site (Province) & Type of forestry tenure and year put in place* & Forest products \\
\hline Reformed sites & & \\
\hline Lampung & $\begin{array}{l}\text { Partnership forestry (1991) } \\
\text { Community forestry (2000) } \\
\text { Community plantation forestry (2010) }\end{array}$ & $\begin{array}{l}\text { Coffee, rubber, timber and non-timber forest } \\
\text { products }\end{array}$ \\
\hline West Kalimantan & $\begin{array}{l}\text { Partnership forestry (1996) } \\
\text { Community forest (2011) }\end{array}$ & Rubber, non-timber forest products, wild game \\
\hline Non-reformed sites & Timber and non-timber forest products; wild game \\
\hline Maluku & Customary forest & Damar (Shorea javanica) \\
\hline Lampung & Customary forest &
\end{tabular}

* Refers to the year the community received legal status of the program or scheme. Implementation depends on support from the company/ state-owned enterprise (partnership forestry) or local government and other actors (community forestry, community plantation forestry) so may be significantly after the legal award.

through two social forestry schemes (partnership forestry and community forestry in 1996 and 2011, respectively); and iii) areas with informal customary land management and no forest tenure reform (one village in Lampung Province and five villages in Maluku Province).

\section{Reformed forest tenure sites}

Community forestry reforms in some study sites of Lampung Province were implemented in 2000 and so are more advanced than those in West Kalimantan Province. Additionally, partnership forestry in Lampung Province was implemented in 1991. Key to this successful land tenure reform has been the full support from local government as well as high exposure to external actors, i.e. nongovernmental organizations and research institutions.

In West Kalimantan Province, the community is dominated by the Dayak ethnic group, which formerly owned customary forest territory that overlapped with 

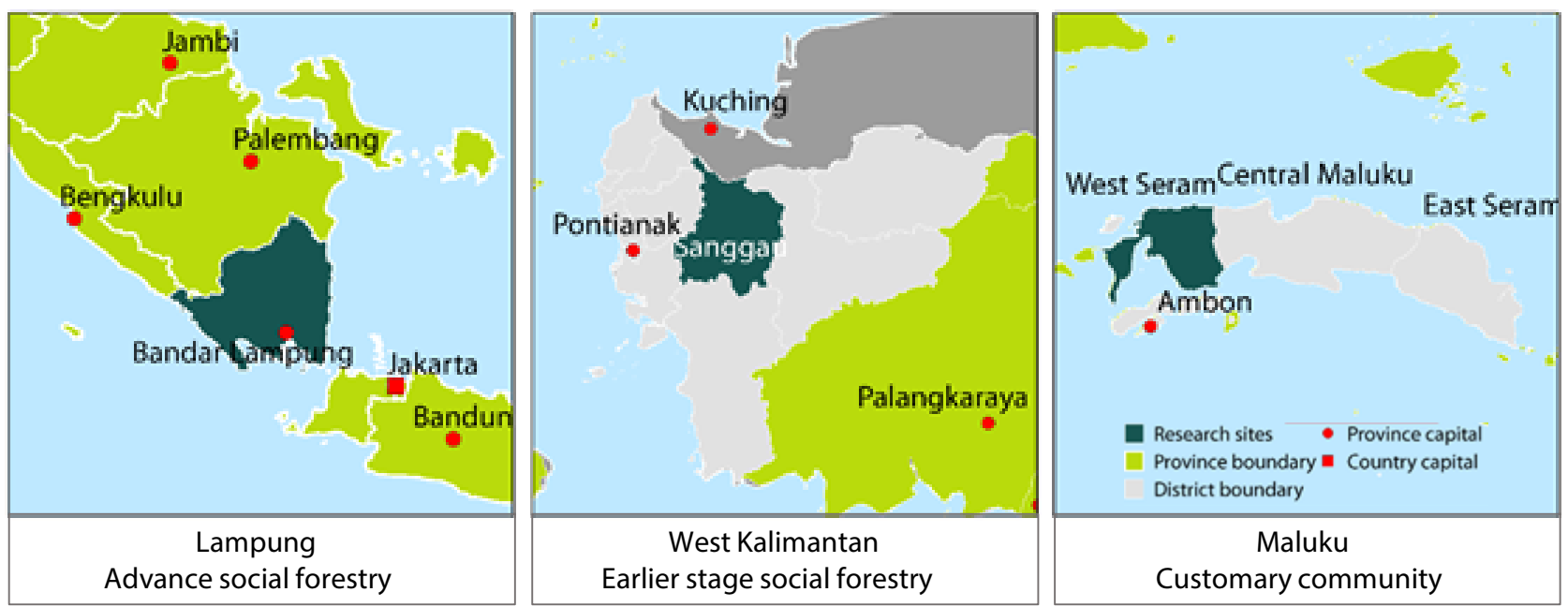

Figure 2. Research sites located in three provinces of Indonesia

state forest. This overlap placed the community in a vulnerable position given that the customary forest use had no legal recognition and so the state had legal right to determine land use (including selling private concessions resulting in the loss of community access to the forest). Moreover, community activities, such as timber extraction, within the state forest were considered illegal. Local non-governmental organizations and the Forestry and the Environmental Research Development and Innovation Agency of the Government of Indonesia (FOERDIA ${ }^{4}$ supported the community to establish community forestry. When the research for this paper was conducted in 2014, the community forestry had only been in place for three years so had yet to make a significant contribution to incomes and livelihoods. Expansion of oil palm and timber plantations was also occurring in some areas, which later became the choice of some community members in managing their land to earn income.

Partnership forestry was implemented in West Kalimantan in 1996 supported by a logging concession company and state-owned enterprise. The forest is also part of the corporate social responsibility program for the community living in and or around the concession, which has helped to improve local incomes.

Prior to the implementation of the reforms in both provinces, the local communities had limited legal access to forest land and resources (Siscawati et al. 2017).

\section{Non-reformed forest tenure sites}

The sites with no forest tenure reform comprised six villages in production and protection forests: five in 532 ha of customary

4 Later renamed as Badan Penelitian, Pengembangan dan Inovasi (Research, Development and Innovation Agency). forest that overlaps with state forest in Seram Bagian Barat District in Maluku Province, and one, Pahmungan village, covering 29,000 ha in Lampung Province. Maluku Province has a strong customary forest management system. Individual or communal land ownership has overlapped with state forest since legal reform was enacted in 1999.5 Extraction of timber and non-timber forest products and wild game is commonly practiced by farmers and regulated by customary institutions.

Pahmungan forest in Lampung Province was officially recognized in 1998 as a Forest for Special Purposes (Kawasan dengan Tujuan Istimewa) but subsequently lacked local government support for implementing any forest reforms. Informal customary land management has therefore continued to be practiced for over 50 years through a traditional agroforestry system of Repong Damar (Damar forest gardens). Villagers harvest gum resin from Shorea javanica to substitute their subsistence income and can earn up to USD 3.65 a day (CIFOR 2018). The gum resin is widely used in industry for cosmetics and textiles and also as a food additive (getah damar).

\section{Perceived Food Security Measure}

Data from the three provinces were collected in 2016 from intra-household surveys, key informant interviews, focus group discussions and document analysis. Existing levels of food security were measured using the following question: "How often in last year you have you had problems in satisfying

5 Forestry Law No. 41/1999 has established and declared all customary territory falls within 'state forest'.

6 Repong Damar is a unique practice of agroforestry found in Lampung Province that has a canopy structure very similar to that of natural forest (Laura and Darmawan 2020). 


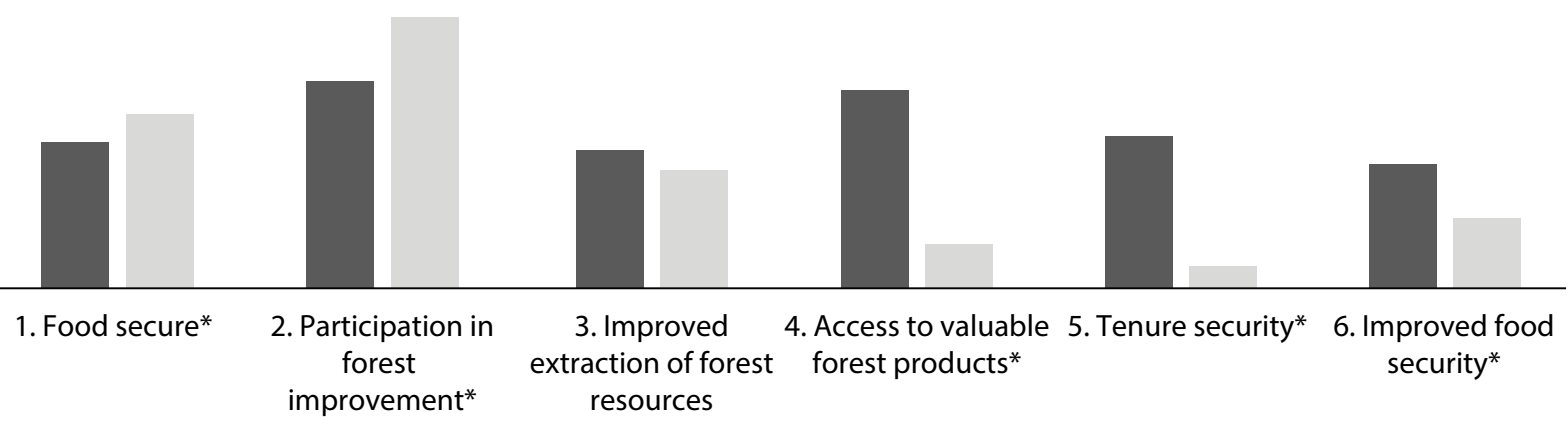

Reformed forest tenure

Non-reformed forest tenure

Figure 3. Perceived food security and access to forest resources in reformed forest tenure and non-reformed forest tenure sites

Note: * denotes a significant difference between areas with and without forest tenure reform

the food needs of the household?". Those who answered "no problem at all" were recorded as being food secure. Information from the qualitative data collection were also included. Communities' perceptions of the change in food security after forest tenure reform was measured using the following question: "How does the situation of household food needs compare with xx years ago?". Those who answered "in better condition" were recorded as having a perception of better food security. Based on the focus group discussions and key informant, for non-reformed sites, the reference of number of years prior to reform was 16-17 years, ${ }^{7}$ and for reformed sites, it was 5-16 years, depending on the village and type of reform.

Further analysis was made of four variables that measured communities' perceptions of added value from forest tenure reform. Households were asked i) if they had an opportunity to collect valuable ${ }^{8}$ forest products, ii) how often they attend meetings about forest use, management and disputes; iii) whether forest tenure reform resulted in more or less restrictive use and access to resources and improved forest management; and iv) if extraction of forest resources had improved or worsened. Additionally, details of household characteristics were obtained. Finally, the relationship between village development and food security was factored into the analysis using the Village Development Index.

7 The changed over time across tenure regime sites is different, e.g. in reformed areas the changed started 5-20 years ago in Lampung (community-based forestry, community-based timber plantations and partnership forestry) and 4-19 years in West Kalimantan (community-based and partnership forestry), and we used a cut-off of 16-17 years ago for nonreformed areas (Maluku and Lampung/KDTI), see also Table 1.

8 The term 'valuable' refers to timber or non-timber forest products that can be sold in the marketplace.

\section{Findings and discussion}

\section{The effects of forest tenure reform on current food security}

Our field data revealed that communities living without forest tenure reform under customary management laws perceived themselves to be more food secure $(60 \%)$ than those with forest tenure reform $(49 \%)$ (see Figure 3.1).

Our analysis to find out determinant of perceived food security status indicated that the perception of households current level of food security is more related to level of development of a village than the presence or absence of tenure reform. Three measures of village development are significantly correlated with perception of food security: infrastructure development, level of public services and level of governance. All villages in the study are categorized as developing villages and there was no difference in the Village Development Index between reformed and nonreformed sites. Level of village development is related to access to markets, which has implications for communities' access to different food types and for their ability to sell forest products. Access to markets can influence perceptions of food security.

The proportion of households involved in forest improvement (Figure 3.2) was significantly higher in areas without forest tenure reform (93\%) than in sites with reform (71\%). Our household survey revealed that improvement of those forests under customary law has regularly been undertaken by the community as part of traditional forest management and/or of an annual program with local governments. In contrast, although in areas with reformed 
forest tenure tree planting must be carried out by farmers as a condition of implementing social forestry, the number of trees planted depends on the farmer's ability to buy seedlings, and we observed that some farmer groups have little motivation to plant trees.

The study also makes a distinction between extraction of forest products and valuable forest products. While extraction of forest products refers to resources that have both an economic and non-economic value, valuable forest products refers only to forest products, timber or non-timber forest products that can be sold in the marketplace. In addition, different forest tenure regimes (customary forest, production forestry, protected forest) involve different rules in forest resource extraction. For example, with regard to the former, improvements in extraction of forest products showed similar results (see Figure 3.3), but communities reported that extraction was less restrictive in non-reformed forest tenure sites than in reformed sites. In this study, the areas with reformed forest tenure are located in protection or production forest. As part of social forestry requirements, the community must plant multi-purpose trees to improve the forest condition. Additionally, some regulations, particularly in protected forest zones, stipulate that farmers are only allowed to collect non-timber forest products. In the areas without reformed forest tenure, customary rules still allow farmers to cut trees for their own use (even though this is considered illegal).

However, with regard to the latter, customary forest tenure appears to offer communities less opportunity to collect valuable forest products (14\% of households reported access) than reformed tenure (67\%) (Figure 3.4). This reflects the differing regulations. With community forestry in forest production zones, communities are allowed to harvest valuable timber and non-timber forest products. In contrast, harvesting valuable forest products is more restricted under customary forest tenure, in particular where community forest overlaps with state forest. Officially, timber extraction is only allowed for subsistence use with permission from village leaders and is forbidden for commercial purposes.

The findings also show that greater food security was perceived by those who did not obtain valuable forest products. This is probably due to the presence of other income-generating activities from agriculture or cash crops, e.g. USD 70-100 per month from coffee in Lampung (with advanced forest reform) and USD 5-35 per month from coconut and damar in Maluku and Pahmungan, respectively (with no forest reform). In contrast, households who rely solely on obtaining forest products are more prone to experiencing food shortages, hence their low perception of food security.
To understand these results overall, we must consider the customary arrangement of the areas with no forest tenure reform in this study. Maluku Province has a strong customary system and the people value their forest as a place to forage for, e.g. sago, the staple food, and as a source of fruit, vegetables, game, spices and wood for timber and cooking. These varied food sources are known to improve the communities' perception of food security (Peng et al. 2018). Forest improvements through tree and cash crop planting may also be contributing to the provision of alternative incomes and diets. The traditional customary system is still used to protect the communities' forests and resources for future use and the communities have been working well to manage their land, albeit without formal access. Customary norms have provided a good framework for ensuring that the forest is managed well, and the community may have gained from this.

The perception of tenure security is also key in influencing farmers' decisions on investments in land and forest. As expected, the proportion of respondents who perceived that they had tenure security was much higher in reformed forest tenure sites (52\%) than in non-reformed sites (5\%) (see figure 3.5). Perception of forest tenure security is also associated with perception of improved food security.

\section{The effects of forest tenure reform on changes in food security}

\section{Our findings show that households in areas with reformed forest tenure are more likely to perceive an improvement in their food security after forest reform (Figure 3.6) than those in non-reformed sites (who} were simply comparing to $16-18$ years earlier). Given that non-reformed sites have higher levels of food security, however, this suggests an important change in forest access with reforms.

Level of well-being, participation in forest improvement and increased ability to extract forest resources and access valuable forest products were positively correlated with a perceived improvement in food security, along with two measures of village development (infrastructure and governance). Level of public services was negatively correlated with households' perceptions of change in food security.

In qualitative responses, communities in reformed sites reported greater levels of harvests than in non-reformed sites. This correlates with our findings that those in reformed sites have been able to expand their agricultural land. We found no difference between respondents from reformed and nonreformed sites in receiving support from household members and the government, availability of cash or ability to sell forest products. 
The type of forest reform may affect the pathway to improving communities' food security. Community plantation forestry and partnership forestry may increase access to economic benefits from timber production, which can improve purchasing power for a more varied diet. For community forestry, our study showed that non-timber forest products and cash crops, such as coffee (in Lampung Province) and rubber (in West Kalimantan) from plantations are the main source of livelihoods and have gradually increased communities' incomes. In production forests, communities may have better access to forests over several years to conduct activities that provide economic returns. Hence, access to these economic benefits may all positively influence the perception of food security over time.

\section{Pathways for improved food security}

Implementing forest tenure reform may provide economic benefits which positively influence food security, albeit indirectly. Households' perceptions of food security were more highly correlated with individual characteristics and village development than forest reform status. However, significantly more households in areas that had experienced forest tenure reform perceived an improvement in their food security compared to those without tenure reform. In other words, prior to reform households in reform areas were more disadvantaged in terms of access to forest resources, hence the tenure reform increased their access, which influenced their perception of food security.

There was no significant difference between education levels and size of household plot for households with and without reformed forest tenure: communities in the reformed sites have lower levels of education but more land than those in non-reformed areas. Controlling these variables is thus important in estimating the relationship between reform status and food security.

\section{Acknowledgment}

CIFOR's 'Global Comparative Study on Forest Tenure Reform' was funded by the European Commission and the Global Environmental Facility (GEF) with technical support from the International Fund for Agricultural Development (IFAD) and the United Nations Organization for Food and Agriculture (FAO). We wish to thank Anne Larson and Amy Ickowitz for their review and comments, and Mohammad Agus Salim for providing map. The opinions expressed in this paper represent the analysis of the authors and do not necessarily reflect the views of CIFOR, CGIAR or the financial sponsors. This study forms part of the CGIAR Research Program on Policies, Institutions and Markets (PIM), led by the International Food Policy Research Institute (IFPRI), and the CGIAR Research Program on Forest, Trees and Agroforestry (FTA), led by CIFOR.

\section{Conclusion}

Improving forest tenure security by granting forest rights to local communities has become one objective of forest tenure reform in Indonesia. This study indicates that the perception of current levels of food security is more related to the level of development (based on the Village Development Index) of a village than the presence or absence of tenure reform. This has been illustrated by our findings in areas with no forest reform, where the practice of customary law maintains biodiversity and forest condition, thus improving customary communities' perception of their food security.

However, respondents in reformed tenure areas demonstrated that their rights were legally recognized under tenure reform and that they are more likely to perceive that their food security has improved over time compared to those living in non-reformed areas. Increased access to economic benefits as a result of forest tenure reform may indirectly improve food security of those living in reformed tenure areas.

This study is limited by the fact that food security is proxied by the respondents' perceptions. Further research would benefit from a robust measure of food security, e.g. by considering the four dimensions of food security: food availability, food access, utilization and stability. Additionally, a comparative analysis of food security prior to and following forest tenure reform in the same area would enable the benefit of the program to be assessed and so inform future policy.

\section{References}

Badan Perencanaan Pembangunan Nasional dan Badan Pusat Statistik. 2015. Indeks Pembangunan Desa 2014. Tantangan Pemenuhan Standar Pelayanan Minimum Desa. Jakarta CIFOR [Center for International Forestry Research]. 2018. Why social forestry: Securing the sap. https://forestsnews.cifor. org/55744/why-social-forestry-securing-the-sap?fnl=CIFOR.

Daniggelis E. 2003. Women and "wild" foods: Nutrition and household security among Rai and Sherpa forager-farmers in eastern Nepal. In Howard PL. ed. Gender relations in biodiversity management and conservation. Zad Books. pp. 83-95.

FAO [Food Agriculture Organization).2006. Food Security. Policy brief June 2006 Issue 2. FAO. https://www.fao.org/ fileadmin/templates/faoitaly/documents/pdf/pdf_Food_ Security_Cocept_Note.pdf

García, M. D. M. H. (2013). The role of women in food security. Cuadernos de estrategia, (161), 82-96.

Herawati T, Liswanti N, Banjade MR, Mwangi E. 2017. Forest tenure reform implementation in Lampung province: From scenarios to action. Infobrief no. 169. Bogor, Indonesia: CIFOR. https://www.cifor.org/knowledge/publication/6418 
Holden ST and Ghebru H. 2016. Land tenure reforms, tenure security and food security in poor agrarian economies: Causal linkages and research gaps. Global Food Security 10: 21-28. https://doi.org/10.1016/j.gfs.2016.07.002

Ickowitz A, Rowland D, Powell B, Salim MA and Sunderland T. 2016. Forests, trees and micronutrient-rich food consumption in Indonesia. PLOS ONE 11(5): 1-15. https:// doi.org/10.1371/journal.pone.0154139

International Union of Forest Research Organizations. 2015. Forests, trees and landscapes for food security and nutrition contributing to the "Zero Hunger Challenge."

Larson AM, Monterroso I, Liswanti N, Herawati T, Banana A, Cantuarias P, Rivera K and Mwangi E. 2019. Models for formalizing customary and community forest lands. The need to integrate livelihoods into rights and forest conservation goals. Infobrief No.253. Bogor, Indonesia: CIFOR. https://www.cifor.org/knowledge/publication/7273/ Laura CT and Darmawan AA. 2020. Monitoring agroforestry for REDD+ implementation using remote sensing data and geographic information system: A case study of Repong Damar, Pesisir Barat Lampung. IOP Conference Series. Earth and Environmental Science; Bristol 538:1. https:// iopscience.iop.org/issue/1755-1315/538/1

Lutomia CK, Obare GA, Kariuki IM, Muricho GS and Yildiz F. 2019. Determinants of gender differences in household food security perceptions in the western and eastern regions of Kenya. Cogent Food and Agriculture 5(1): 1694755. https://doi.org/10.1080/23311932.2019.1694755

Manlosa AO, Hanspach J, Schultner J, Dorresteijn I and Fischer J. 2019. Livelihood strategies, capital assets and food security in rural Southwest Ethiopia. Food Security 11(1): 167-181. https://doi.org/10.1007/s12571-018-00883-x

Pawera L, Khomsan A, Zuhud EAM, Hunter D, Ickowitz A and Polesny Z. 2020. Wild food plants and trends in their use: From knowledge and perceptions to drivers of change in West Sumatra, Indonesia. Foods 9(9): 1-22. https://doi. org/10.3390/foods 9091240

Rights and Resources Initiative. 2020. Estimated area of land and territories of indigenous peoples, local communities and Afro-descendants where their rights are not recognized. Washington DC: Rights and Resource Initiative.

Peng W, Dernini S and Berry EM. 2018. Coping with food insecurity using the sociotype ecological framework. Frontiers in Nutrition 5(November). https://doi.org/10.3389/ fnut.2018.00107

Siscawati M, Banjade MR, Liswanti N, Herawati T, Mwangi E, Wulandari C, Tjoa M and Silaya T. 2017. Overview of forest tenure reforms in Indonesia. Working paper 223. Bogor, Indonesia: CIFOR. https://doi.org/10.17528/cifor/006402

Sukara E. 2014. Tropical forest biodiversity to provide food, health and energy solution of the rapid growth of modern society. Procedia Environmental Sciences 20: 803-808. https://doi.org/10.1016/j.proenv.2014.03.097

Sunderland TCH. 2011. Food security: Why is biodiversity important? International Forestry Review 13(3): 265-274. https://doi.org/10.1505/146554811798293908

Sunderland T, Powell B, Ickowitz A, Foli S, Pinedo-Vasquez M, Nasi R and Padoch C. 2013. Food security and nutrition: The role of the forest. Discussion Paper. Bogor, Indonesia: CIFOR

\begin{tabular}{|c|c|c|}
\hline CGIAR & $\begin{array}{l}\text { RESEARCM } \\
\text { FOGRAM ON } \\
\text { Policies, } \\
\text { Institutions, } \\
\text { and Markets } \\
\text { Ledby IFPRI }\end{array}$ & $\begin{array}{l}\text { The CGIAR Research Program on Policies, Institutions, and Markets (PIM) leads action-oriented research } \\
\text { to equip decisionmakers with the evidence required to develop food and agricultural policies that better } \\
\text { serve the interests of poor producers and consumers, both men and women. PIM combines the resources } \\
\text { of CGIAR centers and numerous international, regional, and national partners. The program is led by the } \\
\text { International Food Policy Research Institute (IFPRI). www.pim.cgiar.org }\end{array}$ \\
\hline
\end{tabular}

\begin{tabular}{|c|c|}
\hline bd & $\begin{array}{l}\text { RESEARCH } \\
\text { PROGRAM ON } \\
\text { Forests. Trees and }\end{array}$ \\
\hline CGIAR & Agroforestry \\
\hline
\end{tabular}

This research was carried out by CIFOR as part of the CGIAR Research Program on Forests, Trees and Agroforestry (FTA). FTA is the world's largest research for development program to enhance the role of forests, trees and agroforestry in sustainable development and food security and to address climate change. CIFOR leads FTA in partnership with Bioversity International, CATIE, CIRAD, INBAR, ICRAF and TBI.

FTA's work is supported by the CGIAR Trust Fund: cgiar.org/funders/

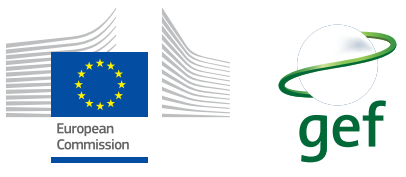

cifor-icraf.org cifor.org | worldagroforestry.org 